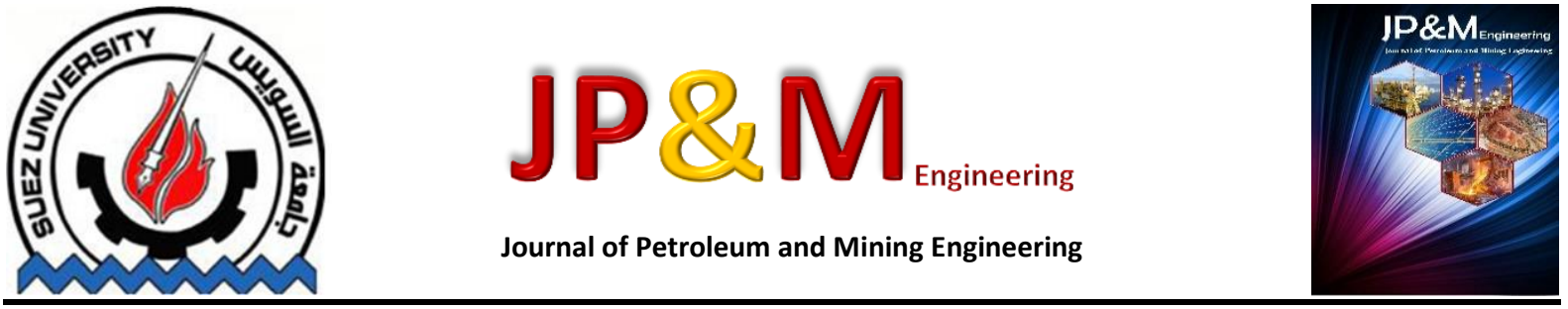

\title{
Process Simulation and Performance Improving of An Existing Ngl Plant
}

\author{
Mohammed S. M. Saliem*, ${ }^{a}$, Ahmed A. Bhran ${ }^{b}$, Galal M. Abdel-Aleim ${ }^{b}$ and Atef A. Hady ${ }^{c}$ \\ a El-Wastani Petroleum Company, Damietta, Egypt. \\ b Petroleum refining and petrochemical eng. dept.,Faculty of petroleum and mining engineering, Suez University, Suez, Egypt. \\ ${ }^{c}$ Egyptian Natural Gas Holding Company (E-Gas), Cairo, Egypt.
}

\section{Keywords}

Natural gas; Simulation; NGL Plant

\begin{abstract}
Nowadays, gas processing for NGLs (natural gas liquids) and LPG (liquefied petroleum gas) recovery is becoming of great interest due to the increase in market demand as well as the higher sale prices of these products. However, many of the present NGL and LPG recovery units in operation don't give the desired revenue. This study focuses on the retrofitting of El-Wastani petroleum company (WASCO) which is one of the most important NGL/LPG recovery units constructed in Egypt. The performance of this unit has been simulated and improved by modifying different factors. The most important studied factors are capacity, feed type (composition), and recovery efficiency. The results showed that the lean gas feed (low butanes) is the worst type which gives the same LPG recovery efficiency but with low productivity and higher energy requirements compared with rich feed (more butane). Hence, for confirming the plant improvements at any feed composition, the effect of gas feed capacity on the plant profitability will be based on lean gas feed. According to the simulation and optimization results, the growing economic opportunities offered mainly when the gas feed capacity increases by $25 \%$. In this case, the pay-back periods of the added equipment were characterized by high or reasonable investment strength, which means that all modification costs will be recovered within short or acceptable periods. Both new and plants in operation will benefit from the modifications and performance improvements discussed in this study. This work can be taken as guidelines to aid operating companies improve their profits resulted from existent plants retrofitting.
\end{abstract}

\section{Introduction}

Natural gas liquids, or NGLs, are valuable products derived from the processing of natural gas and refining of crude oil. Five major NGLs - ethane, butane, isobutane, propane and natural gasoline - are used by petrochemical companies as feed stocks and by refineries as blending and processing components. When NGLs are extracted from natural gas, the volume and BTU content of the gas are reduced. That makes NGL processing a key factor in the supply/demand balance for natural gas. In addition, some producing regions produce very rich (high-BTU) gas that must be processed before the gas can be delivered to a pipeline for transportation to market. In areas where not enough natural gas processing capacity is available, gas production must be curtailed down to the available capacity [1,2]. Designing a new gas plant or upgrading an existing plant is a very challenging endeavor. Past studies have shown that up to $80 \%$ of the cost of a plant may be committed during conceptual engineering [3]. Therefore, when designing a new plant or upgrading an existing plant it is very important to understand and select the right process conditions to minimize capital and operating expenses [4].

In many cases, however, a process retrofit can dramatically improve the economics of an existing plant by reducing the unit operating cost and boosting product revenues. Retrofitting the existing plants to a more efficient process can provide the following benefits [5].

- Higher process efficiency reduces the energy consumption per unit of gas processed.

- Higher process efficiency allows increased plant throughput with the same gas compression power, reducing the fixed costs per unit of gas processed.

- Increased plant throughput translates into greater product sales and revenue. 
- Liquid recovery efficiency can also be increased, further raising product sales and revenue.

- Process flexibility can be improved by adding efficient ethane rejection capability.

El-Wastani Petroleum Company (see Figure 1) operates wells network in order to process the feed gas stream to deliver sales gas, stabilized condensate, and liquefied petroleum gas (LPG) via central processing facilities (CPF) plant. The project is structured around the following two fundamental principles:

- To ensure early gas production (minimum 150 MMSCFD) and condensate stabilization.

- To utilize a deep-cut design that allows separation of components from the inlet feed to produce an LPG product.

Based on the above two principles, the project have been split in two stages:

1. Stage I which is comprised of a hydrocarbon dew point (HCDP) control unit. In this unit removal of liquid hydrocarbons is achieved by using of propane based Mechanical Refrigeration with ethylene glycol (EG) injection. After that the recovered hydrocarbons are admitted to a stabilizer tower with an overhead gas re-injection compression unit.

2. Stage II in which LPG Recovery unit comprising of molecular sieve based dehydration unit, turbo-expander unit, deethanizer system, de-butanizer system, LPG metering and storage systems.

The plant has been designed for three different operating modes [6]:

1. Stage I operation with mechanical refrigeration.

2. Stage II operation with mechanical refrigeration and turbo-expander.

3. Stage II operation with mechanical refrigeration and J-T valve.

Due to the rapid increasing of natural gas and NGL consumption, the need arises to enhance the performance of ELWASTANI plant to get higher recovery level of NGL as well as higher revenue. In the following sections, the way uses to analyze the process and the options uses to maximize the plant profit will be exhibited.

\section{Research methodology}

The objective of this article is to study the major factors which could lead to some improvements in the performance and energy requirements of El-Wastani plant constructed in Egypt for producing NGL especially LPG.

The most effective factors studied in this work are as the following:

- Gas feed composition (more or less butanes).

- Capacity increase.

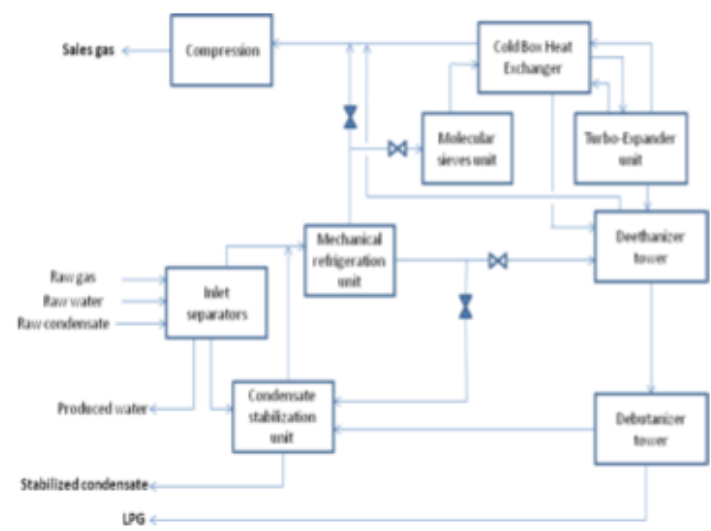

Figure 1 El-Wastani Central Processing Facilities(CPF) block flow diagram[6].

The simulation package used in this study is HYSYS-3.2 which is based on Peng-Robinson equation of state for calculations [7].The plan of this study is constructed as in the following steps:

1. Studying the performance of the plant at different feed compositions and at multiflow rates quantities ranges from 160 to 220 MMSCFD. Gas feed capacity is based on raw gas with 20 BBLs of raw condensate per 1 MMSFCD of raw gas. The butane recovery level is fixed at $80 \%$. Simulations are carried out for original, leaner (less butanes) and richer (more butanes) feed compositions.

2. Comparing the results obtained from the previous section is performed to select the most critical feed composition based on energy consumption. The most critical feed composition is the one consumes more energy than the others. The improvement of the plant performance at this selected composition will ensure its performance improvements at other feed compositions.

3. Finally, the cost estimation based on return on investment (R.O.I.) is done for the selected feed composition to determine the optimum inlet gas flow rate at which the plant could be operated to maximize its profitability.

\section{Equipment sizing}

Equipment size is calculated by using the output data from Aspen Hysys simulation program to get the proper specification of the concerned equipment such as area with heat exchanger and power in the case of compressor, etc.[8]. For example the exchanger area was calculated by using the duty given from Aspen Hysys. The log mean temperature difference was calculated for each re-boiler and condenser as in the following calculations. Duty: $Q$ (given from Aspen HYSYS)

$$
\Delta t=L M T D=\frac{\Delta T_{1}-\Delta T_{2}}{\ln \left(\frac{\Delta T_{1}}{\Delta T_{2}}\right)}
$$

Where LMTD is the log mean temperature difference. $\Delta \mathrm{T} 1$ is the temperature difference between the hot inlet stream and cold outlet steam and $\Delta T 2$ is the difference between the hot outlet stream and the cold inlet stream. Area of the 
equipment (condenser or re-boiler) can be calculated from the following relationship:

$$
A=\frac{Q}{K \Delta t}
$$

\section{Cost Estimation}

An estimate of the capital investment for a process may vary from a pre-design estimate based on little information to a detailed estimate prepared from complete drawings and specifications. These estimates are called by a variety of names, but there are five estimate categories represent the accuracy range and designation normally used for design purposes. These five famous estimates are order-of magnitude, study, preliminary, definitive and detailed estimates. The accuracy of these estimates are ranging from + or -30 percent to + or -5 percent respectively [9]. According to our current status of data availability and calculation stage, we followed the Preliminary estimate (budget authorization estimate). This choice is based on sufficient data used to permit the estimate to be budgeted. Probable accuracy of this estimate is within + or -20 percent.

\section{Fixed capital cost}

The fixed capital cost is estimated to get an approximate price for the total plant installed and running. These calculations are based on given percentages(see table 1) [9].

Table 1:Fixed Capital Cost Percentage $[9,12]$.

\begin{tabular}{|lc|}
\multicolumn{1}{|c|}{ Fixed Capital cost } & $\begin{array}{c}\text { Percent of } \\
\text { delivered } \\
\text { equipment cost }\end{array}$ \\
\hline $\begin{array}{l}\text { Purchased equipment } \\
\text { delivered, E }\end{array}$ & 100 \\
$\begin{array}{l}\text { Purchased equipment } \\
\text { installation }\end{array}$ & 47 \\
Instrumentation and & \\
controls (installed) & 36 \\
Piping (installed) & 68 \\
Electrical systems (installed) & 11 \\
Buildings (including & 18 \\
services) & 10 \\
Yard improvements & 70 \\
Services facilities (installed) & 33 \\
Engineering and supervision & 41 \\
Construction expenses & 4 \\
Legal expenses & 22 \\
Contractor's fee & 44 \\
\hline Contingency & \\
\hline
\end{tabular}

Equipment costs are calculated according to cost estimation techniques where, the cost of the new equipment, $\mathrm{Cn}$, is equal to the known equipment cost, $\mathrm{Ck}$, times the ratio of the two plants' capacities raised to a fractional power. That is:

$$
C_{n}=C_{k}\left(\frac{V_{n}}{V_{k}}\right)^{F}
$$

take a value between 0.4 and 0.9 , depending on the type of plant. In our estimating technique, we use a factor value of 0.6 which is often used according to the literature or historical data [10]. In addition to use of Nelson-Farrar indexes, the most proper approximated calculation could be performed to determine the value of the relevant cost at current time. This is done by the comparison with equipment prices which are obtained from El-Wastani Company [11].

\section{Working capital cost}

The working capital is the amount of capital required to start up the plant and to finance the first couple of months of operating before the plant starts earning. This capital is used to cover salaries, raw material inventories and contingencies. It will be recovered at the end of the project and represents a float of money to get the project started. These costs are necessary at start-ups and it implies raw materials and intermediates in the process. The working capital was assumed to be $3 \%$ of the fixed capital cost [12].

\section{Operating Cost}

The operating cost includes all the incremental increase in chemical injection, power, treatment, utility consumption which is needed to achieve the required target of increasing capacity.

\section{Investment Analysis}

Profitability is the measure of the amount of profit that can be obtained from a given situation. It is as common denominator for all business activities. The determination and analysis of profits obtainable from the total cost of investment and the choice of the best investment among various alternatives are major goals of the investment analysis [9].

The determination of optimum flow rate to operate our plant with a new modifications and maximizing the profitability is based on return on investment (ROI) principle. The values from 20 to 30 percentages for the return on investment (ROI) can be used as a rough guide for judging our project retrofitting. Consequently, the decision has to be made on whether to install additional equipment to reduce operating costs or not [13]. The calculations of $\mathrm{ROI}$ are mainly consisting of two major terms as described below:

1. Total capital investment which includes the cost of purchased equipment, installation and foundation, instrumentation, piping, and commissioning works.

2. The net profit which is resulting via productivity increase after excluding the annual increase in operating cost.

ROI $=$

(Total annual income increment-annual increase in operating 
The total capital investment includes the fixed capital cost in addition to the working capital cost. Pay-back is the period of time required for the return on an investment to "repay" the sum of the original investment. Pay-back period can be calculated as bellow:

$$
\text { Pay }- \text { back period }=1 / \text { ROI }
$$

Table 2: Different feed gas compositions.

\begin{tabular}{|c|c|c|c|}
\hline \multirow[t]{2}{*}{ Component } & \multicolumn{3}{|c|}{ Composition in mole fraction } \\
\hline & $\begin{array}{c}\text { Original } \\
\text { feed }\end{array}$ & $\begin{array}{l}\text { Lean } \\
\text { feed }\end{array}$ & $\begin{array}{l}\text { Rich } \\
\text { feed }\end{array}$ \\
\hline Nitrogen & 0.0004 & 0.0011 & 0.0004 \\
\hline $\mathrm{CO} 2$ & 0.0032 & 0.0047 & 0.0032 \\
\hline Methane & 0.8688 & 0.8808 & 0.8666 \\
\hline Ethane & 0.0749 & 0.0714 & 0.0747 \\
\hline Propane & 0.0275 & 0.0233 & 0.0274 \\
\hline i-Butane & 0.0084 & 0.0059 & 0.0098 \\
\hline n-Butane & 0.0064 & 0.0046 & 0.0075 \\
\hline i-Pentane & 0.0031 & 0.0021 & 0.0031 \\
\hline n-Pentane & 0.0017 & 0.0011 & 0.0017 \\
\hline n-Hexane & 0.0019 & 0.0014 & 0.0019 \\
\hline n-Heptane & 0.0013 & 0.0011 & 0.0013 \\
\hline n-Octane & 0.0006 & 0.0006 & 0.0006 \\
\hline n-Nonane & 0.0002 & 0.0002 & 0.0002 \\
\hline n-Decane & 0.0001 & 0.0002 & 0.0001 \\
\hline $\mathrm{H} 2 \mathrm{O}$ & 0.0015 & 0.0015 & 0.0015 \\
\hline Total & 1 & 1 & 1 \\
\hline
\end{tabular}

\section{Plant Feed Gas Chemical Composition}

In the process of plant simulation, the effect of various feed compositions will be taken into account. This effect on the performance of the process as a whole in accordance of leanness and richness of butanes in the feed (see table 2) was studied.

\section{Results and Discussion}

\section{Effect of feed gas composition on the plant performance}

This section is started with illustrating the relationship between feed gas compositions and the change could appear on the variant variables (such as re-boilers duty, compressors horsepower, heat exchangers heat duties, and etc.) of the process. The performance of the process at original feed gas composition was studied as in the following steps:-

\section{Glycol re-boiler duty}

The water content of a gas depends on system pressure and temperature and the composition of the water containing gas [14], where water content increasing with gas richness increase (high specific gravity means higher saturation volumes of water). As shown in figure 2, the glycol re-boiler duty increases with increasing of gas feed flow rate but slightly affected by the variation of gas feed composition. This can be interpreted due to the water content in the feed. Water content increases as the leanness of the gas increases due to the lower cooling temperature applied at mechanical refrigeration unit stage which leading to an increasing of the required heat duty of the re-boiler [15].

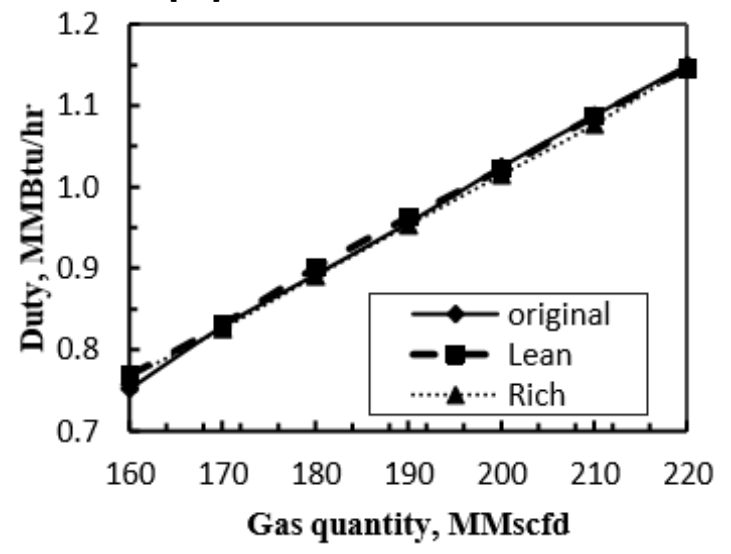

Figure 2 Glycol re-boiler duty versus gas quantity.

\section{Minimum cold temperature (Turboexpander outlet temperature)}

The temperature at which any substance starts to condense is called dew point. This point is directly correlated to the system pressure for one component system or partial pressure of that substance in multicomponents system. The partial pressures of the hydrocarbon components in feed are in turn having relationships with their mole fraction in that gas feed.Figure 2 describes the relationship between minimum cold temperature and gas quantity. From this figure it is clear that the minimum cold temperature decreases in accordance to feed gas composition leanness regardless the increasing of gas feed flow rate. This can be interpreted due to the lower values of desirable components (heavier hydrocarbon components in gas feed) partial pressures with increasing the leanness of the gas feed[16].

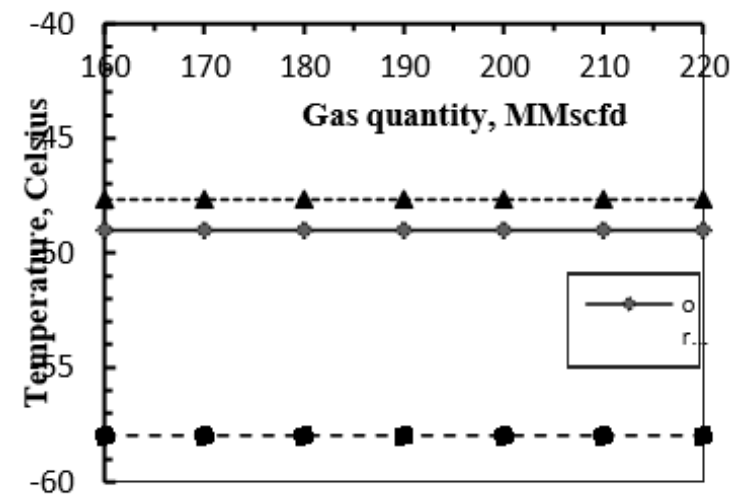

Figure 3 Minimum cold temperature in Celsius versus gas quantity in MMSCFD. 


\section{De-ethanizer overhead gases quantity}

Solid solubility data of hydrocarbons components in low molecular weight solvents are important for use in the design of liquefaction, vaporization, and transport systems for liquefied natural gas (LNG) and liquefied petroleum gas (LPG) [17]. Both temperature and pressure affect hydrocarbon absorption. In general, the lower the temperature and the higher the pressure, the more hydrocarbons will be dissolved in the physical solvent. In some cases, however, the hydrocarbon solubility actually increases with temperature [18]. As shown in figure 4, the deethanizer overhead gas quantity increases in accordance to gas feed flow rate increase. We can see also that overhead gas quantity significantly affected by the variation of gas feed composition where cold temperature varies according to the leanness and richness of the processed gas.

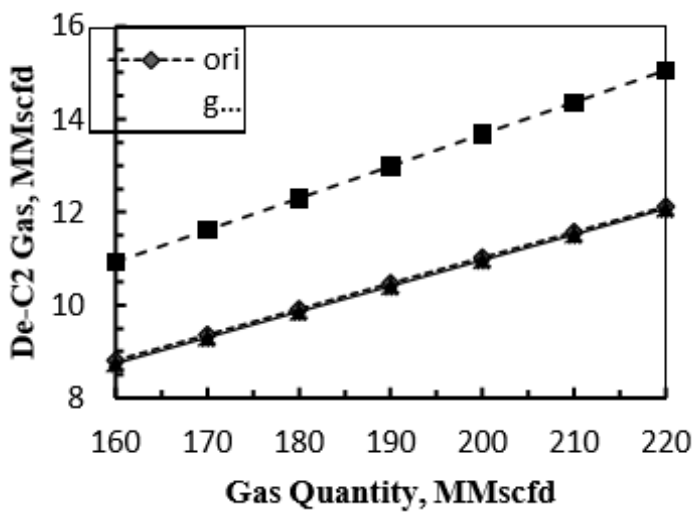

Figure 4 De-ethanizer overhead gas quantity in relation to feed gas quantity in MMSCFD.

\section{De-Ethanizer overhead condenser duty}

Often a part of the condensate is returned (as a reflux) back to the still and is mixed with the outgoing vapor [19]. As shown in figure 5, the condenser duty increases in accordance to the increase of gas feed flow rate. Furthermore, this condenser duty is significantly affected bythe variation of gas feed composition. This duty increases with increasing of light hydrocarbons components which dissolve due to the reduction of cold temperature compared with heavier hydrocarbons as shown in figure 4 .

\section{De-Ethanizer Re-Boiler Duty}

A total condenser is used to produce liquid reflux and distillate product. The re-boiler is a "partial reboiler" (vapor is boiled off a liquid pool)[20]. The de-ethanizer bottoms reboiler is used to strip off the light ends to obtain acceptable product with a reasonable vapor pressure.

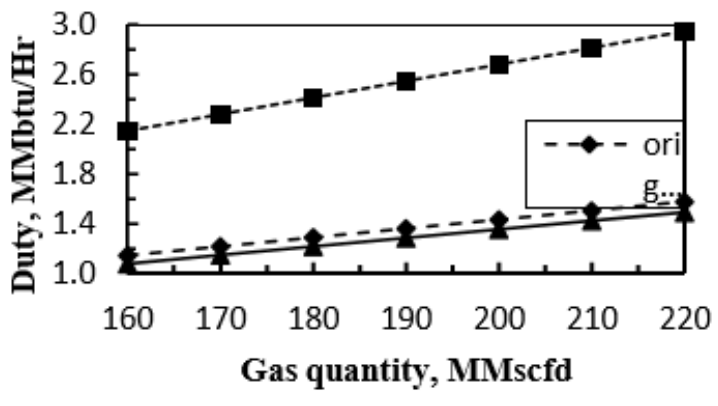

Figure 5 Condenser duty in MMBtu/h versus Feed Gas Quantity in MMscfd.

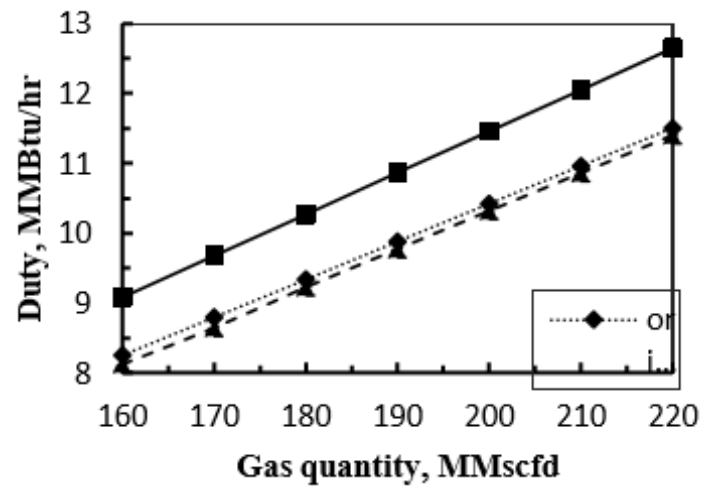

Figure 6 De-ethanizer Re-boiler duty in MMBtu/h versus Feed gas quantity in MMscfd.

As shown in Figure 6, the re-boiler duty increases with increasing the gas feed flow rate. This Figure shows also that the re-boiler duty is significantly affected by the variation of gas feed composition. There fluxed stream is increasing along with extra refrigeration requirement in case of lean gas which required additional heat for light end stripping concerns.

\section{De-Butanizer overhead condenser duty}

De-butanizer overhead condenser utilize the energy admitted to the aerial cooler to condense the overhead product of de-butanizer tower. As shown in Figure 7, the condenser duty increases with increasing the gas feed flow rate. This duty is significantly affected by the variation of gas feed composition in particular in case of rich gas where higher quantities of LPG were recovered.

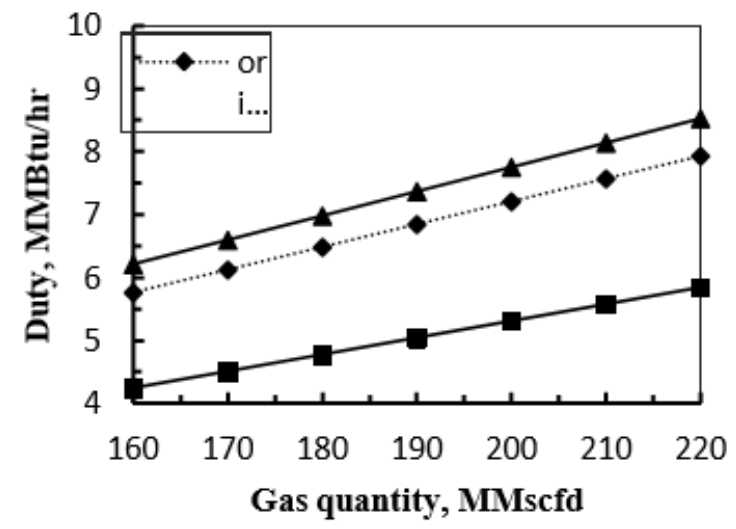

Figure 7 De-butanizer condenser duty versusGas quantity in MMscfd. 


\section{De-Butanizer Re-Boiler duty}

De-butanizer bottom re-boiler utilize the admitted energy to strip off the desirable product (propane, isobutane, and n-butane) of de-butanizer tower. It is clear from Figure 8 that the re-boiler duty increases in relation to gas feed flow rate increase. The variation of gas composition has a highly effect on the reboiler duty especially in case of rich gas where higher quantities of LPG were recovered.

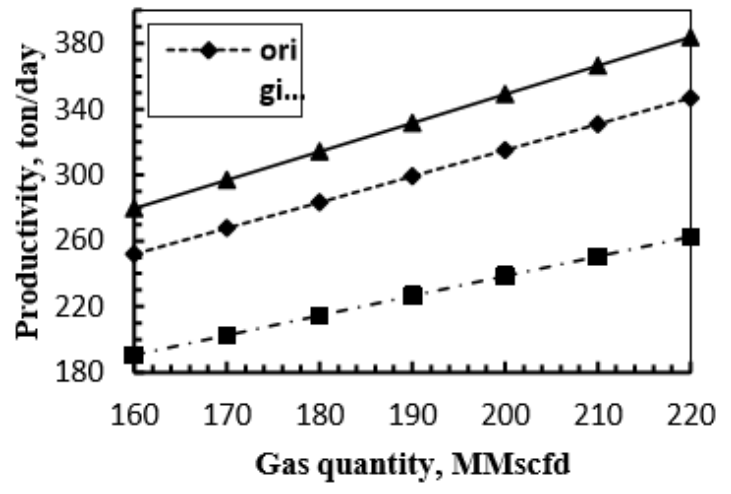

Figure 8 LPG productivity versus gas quantity.

\section{Energy Requirements}

Energy requirements include all energyconsumed equipment such re-boilers duties, condensers power, compressors energy and as we saw in the previous relations between both of fractionation towers utilities. As shown in Figure 9, the energy requirements increase with increasing the gas feed flow rate. It is obvious also that these requirements are significant higher in the case of lean feed than other two feed types. The consumed energy in the section of de-ethanizer unit exceeds the energy saving in de-butanizer tower, so it didn't offset the increasing tendency.

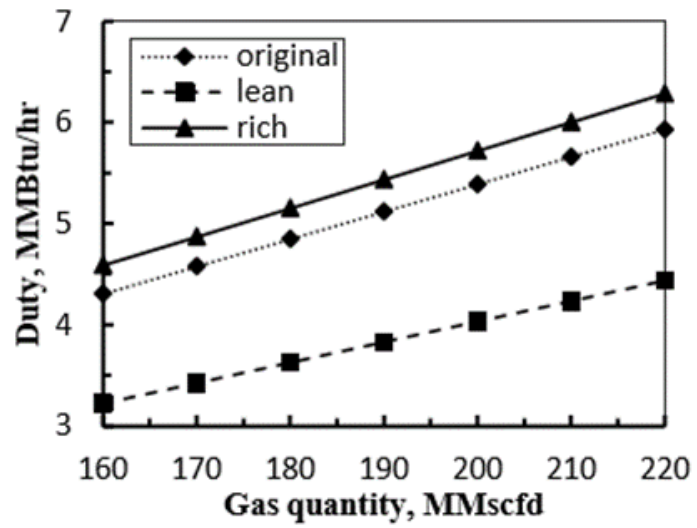

Figure 9 De-butanizer Re-boiler duty versus Gas quantity.

\section{LPG productivity}

The quantity of LPG is directly related to the amount of propane and butanes in the feed gas. It is obvious from Figure 10, that the LPG productivity increases in accordance to gas feed flow rate increase and significantly affected by the variation of gas feed composition in particular in case of rich gas.

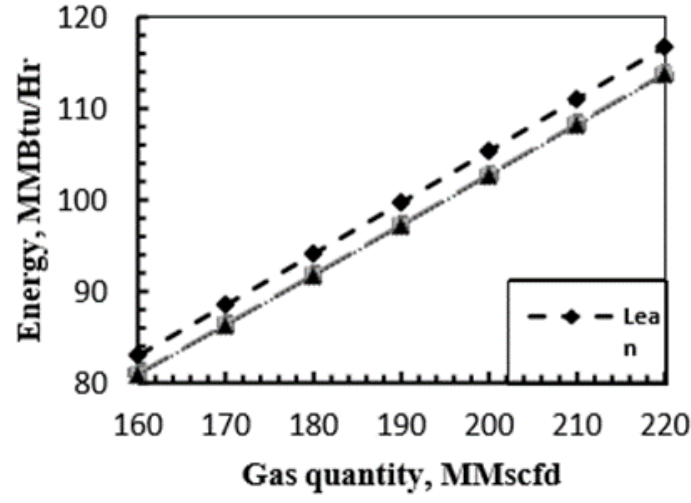

Figure 10 Energy Requirement versus Gas Quantity.

\section{Specific energy consumption}

This relationship determines how much energy should be consumed to produce a ton of LPG, and as shown in figures 9, and 10 respectively that productivity increases in this order lean, original, and rich where the consumed energy differs away and increase in this order rich, original, and lean. So, as shown figure 11 that the specific productivity increases in accordance to gas feed flow rate increase and significantly affected due to the variation of gas feed composition in particular in the case of rich gas where higher productivity and lower energy consumption.

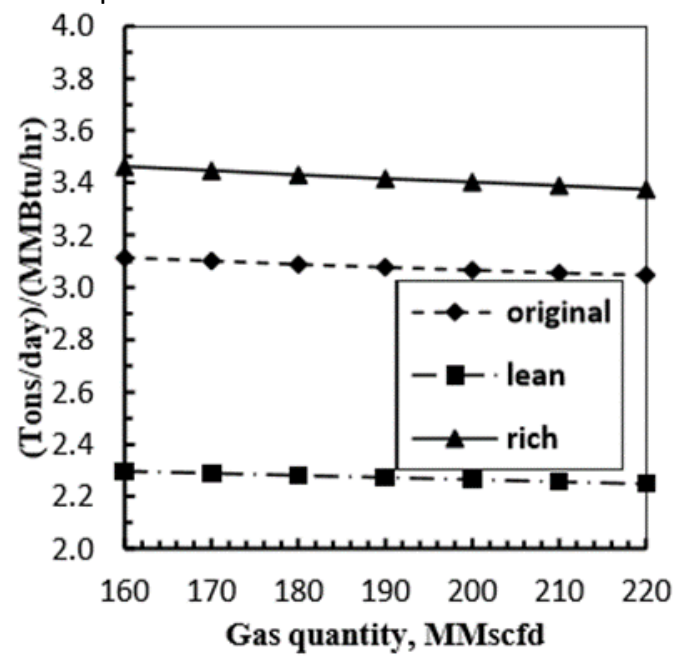

Figure 11 Specific Productivity versus Gas Quantity. 


\section{Capacity Increase Study}

As we study the performance of the plant at several feed gas compositions, we have to determine the profitability of this plant via increase its capacity. It is previously noted that the worth case which needs more energy requirements is for the leaner gas feed. In view of the confirmation of the plant improvements at any feed composition, the effect of capacity on the plant profitability will be based on lean feed. For doing the effect of capacity calculations, the following parameters are of interest:

1. For heat exchangers:-

a) Glycol regeneration re-boiler

b) Inlet gas/gas heat exchanger

c) Gas chiller

d) Cold box

e) De-ethanizer overhead condenser/re-boiler

f) De-butanizer overhead condenser/re-boiler

g) Stabilizer re-boiler/ condensate cooler

2. For compressors:-

a) De-ethanizer overhead gases compressor

b) Stabilizer overhead gases compressor

c) Sale gas discharge compressor

d) Turbo-expander

3. For towers:-

a) Molecular sieve unit dehydrators.

Tables 3-8 present the results of LPG plant simulation at various inlet flow rates. These tables exhibit both the additional requirement and the income profit. As shown in the previous tables, there are many requirements for each flow rate to match the recovery level and operation changes. According to the concept of NelsonFarrar indexes in addition to 0.6 estimate factor rule, the additional requirements cost was calculated and tabulated in the following table (all costs are in MM \$). For the appropriate selection of the optimum flow rate which is between 160 and 220 MMSCFD, the process of decision making may be based on a generic technique such as ROI. The concept of ROI (Return On Investment) is a function of the time required for getting consumed money (additional cost)back (in days, weeks, or months ... etc). Table 8 shows the calculated ROI as well as the time required for money recovery at different gas feed capacity. Figure 12 exhibits the relationship between the gas feed quantity and the time required for money recovery. From this relationship we can select the most economic gas flow rate used to operate our plant at the best profitable conditions. Figure 12 presents also the equation (generated by using Microsoft excel functions) used to fit the relationship between gas feed rate and time required for money pay back.

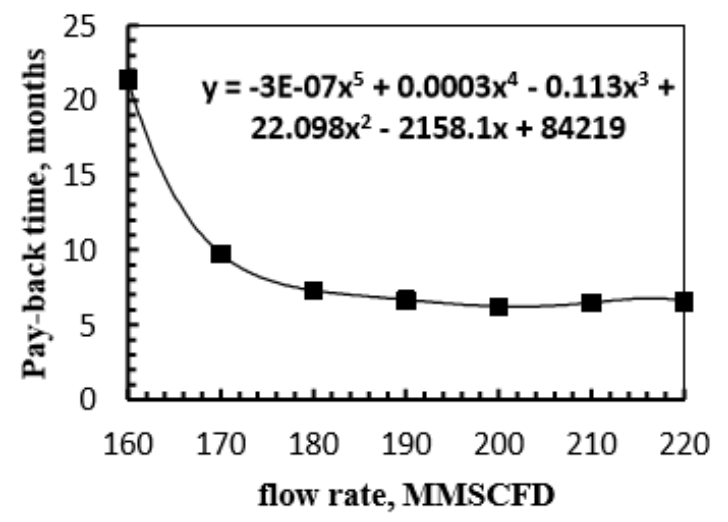

Figure 12 Return on Investment in terms of pay-back time period versus Gas Quantity.

The optimum operating feed capacity is obtained by the differentiation of the generated equation showed in figure 12. After the differentiation of this equation, the optimum condition for operating the plant is at gas feed quantity of 200.158 MMSCFD which can be taken as 200 MMSCFD by considering the data presented in table 8 .

\section{Conclusions and Recommendations}

NGL and LPG plants in operation require continuous innovation and adaptation in process technologies and suitable selection of operating condition in order to increase their revenues. The present work is directed to improving the economics and performance efficiency of El-Wastani plant which is one of most useful units constructed in Egypt to produce LPG from natural gas. Hence, the major factors that could enhance the performance and energy consumption of this plant are studied. The most important factors studied in this work are gas feed type (rich or lean), and gas feed capacity. A comparison of the of the existing plant operation before and after the modification are made using the simulation package of HYSYS-3.2. The simulation results show that the rich gas feed (more butanes) is highly effective due to its higher LPG productivity at lower energy requirements compared to the lean gas feed. Economic analysis has been carried out to determine the performance and profitability of the plant at several gas feed capacities (160220 MMSCFD). From the optimization results, the most efficient and economic operating condition for the lean gas feed is when operating the plant at 2000 MMSCFD; by increasing the original plant capacity by $25 \%$. The use of the previous principals for operating an existing plant gives improved performance in terms of higher NGL and LPG recovery with little increase in power consumption and thus gives enhanced overall economics. This study can be applied on many NGL and LPG plants in operation and new projects. As a result, the profitability of these plants can be increased by the appropriate selection of gas feed type, increasing plant throughput and increasing product recoveries. The future work may be planned to evaluate the profitability of our plant after extra modification in its operation modes. These modes 
may include the recovery efficiency, pressure fluctuations, and operation flexibility.

Table 3 Simulation results of LPG plant in relation of feed gas quantities.

\begin{tabular}{|c|c|c|c|c|c|}
\hline $\begin{array}{l}\text { Gas } \\
\text { Rate }\end{array}$ & $\begin{array}{l}\text { Glycol } \\
\text { re- } \\
\text { boiler } \\
\text { duty }\end{array}$ & $\begin{array}{c}\text { G/G } \\
\text { Heat } \\
\text { Exchang } \\
\text { er }\end{array}$ & $\begin{array}{c}\text { Chiller } \\
\text { of } \\
\text { MRU-I }\end{array}$ & $\begin{array}{l}\text { Mole } \\
\text { Sieve }\end{array}$ & $\begin{array}{l}\text { Cold } \\
\text { Box }\end{array}$ \\
\hline & $\begin{array}{c}\mathrm{MMBt} \\
\mathrm{u} / \mathrm{h}\end{array}$ & MMBtu/h & $\begin{array}{c}\text { MMBtu/ } \\
\mathrm{h}\end{array}$ & $\begin{array}{c}\text { MMSCF } \\
\text { D }\end{array}$ & $\begin{array}{c}\text { MMBtu } \\
\mathrm{h}\end{array}$ \\
\hline Design & 1.00 & 15.57 & 6.70 & 162.00 & 12.80 \\
\hline 160 & 0.77 & 13.90 & 5.31 & 157.80 & 15.98 \\
\hline 170 & 0.83 & 14.77 & 5.64 & 167.70 & 16.98 \\
\hline 180 & 0.90 & 15.65 & 5.98 & 177.60 & 17.98 \\
\hline 190 & 0.96 & 16.52 & 6.31 & 187.50 & 18.98 \\
\hline 200 & 1.02 & 17.39 & 6.64 & 197.40 & 19.99 \\
\hline 210 & 1.09 & 18.26 & 6.97 & 207.30 & 20.99 \\
\hline 220 & 1.15 & 19.13 & 7.30 & 217.20 & 21.99 \\
\hline
\end{tabular}

Table 4 Simulation results of LPG plant as a function offeed gas quantities.

\begin{tabular}{|c|c|c|c|c|c|c|}
\hline \multirow{2}{*}{$\begin{array}{c}\text { Gas } \\
\text { Rate }\end{array}$} & $\begin{array}{c}\text { Expan } \\
\text { der }\end{array}$ & \multicolumn{2}{|c|}{ De-ethanizer } & \multicolumn{2}{c|}{ De-butanizer } \\
\cline { 2 - 7 } & Power & $\begin{array}{c}\text { Conde } \\
\text { nser }\end{array}$ & $\begin{array}{c}\text { Reboil } \\
\text { er }\end{array}$ & $\begin{array}{c}\text { compre } \\
\text { ssor } \\
\text { power }\end{array}$ & $\begin{array}{c}\text { Conde } \\
\text { nser }\end{array}$ & $\begin{array}{c}\text { Reboil } \\
\text { er }\end{array}$ \\
\cline { 2 - 7 } & Hp & $\begin{array}{c}\text { MMBt } \\
\text { u/h }\end{array}$ & $\begin{array}{c}\text { MMBt } \\
\text { u/h }\end{array}$ & Hp & $\begin{array}{c}\text { MMBt } \\
\text { u/h }\end{array}$ & $\begin{array}{c}\text { MMBt } \\
\text { u/h }\end{array}$ \\
\hline \multirow{2}{*}{ Design } & $\begin{array}{c}\text { Max. } \\
1165\end{array}$ & 1.435 & 8.440 & $\begin{array}{c}200.00 \\
0\end{array}$ & 8.458 & 6.835 \\
\hline $\mathbf{1 6 0}$ & $\begin{array}{c}1035.0 \\
0\end{array}$ & 2.15 & 9.09 & 100.60 & 4.24 & 3.22 \\
\hline $\mathbf{1 7 0}$ & $\begin{array}{c}1100.0 \\
0\end{array}$ & 2.28 & 9.68 & 106.10 & 4.51 & 3.42 \\
\hline $\mathbf{1 8 0}$ & $\begin{array}{c}1165.0 \\
0\end{array}$ & 2.42 & 10.27 & 113.20 & 4.78 & 3.63 \\
\hline $\mathbf{1 9 0}$ & $\begin{array}{c}1230.0 \\
0\end{array}$ & 2.55 & 10.87 & 119.60 & 5.04 & 3.83 \\
\hline $\mathbf{2 0 0}$ & $\begin{array}{c}1295.0 \\
0\end{array}$ & 2.68 & 11.46 & 125.90 & 5.31 & 4.03 \\
\hline $\mathbf{2 1 0}$ & $\begin{array}{c}1360.0 \\
0\end{array}$ & 2.82 & 12.05 & 132.20 & 5.58 & 4.23 \\
\hline $\mathbf{2 2 0}$ & $\begin{array}{c}1425.0 \\
2\end{array}$ & 2.95 & 12.65 & 138.50 & 5.84 & 4.43 \\
\hline
\end{tabular}

Table 5 Simulation results of LPG plant as a function offeed gas quantities.

\begin{tabular}{|ccccc|}
\hline $\begin{array}{c}\text { Gas } \\
\text { Rate }\end{array}$ & Reboiler & $\begin{array}{c}\text { Stabilizer } \\
\text { compressor } \\
\text { power }\end{array}$ & $\begin{array}{c}\text { Condensate } \\
\text { cooler }\end{array}$ & $\begin{array}{c}\text { SalesGas } \\
\text { Comp. }\end{array}$ \\
\hline MMBtu/h & Hp & MMBtu/h & Hp \\
\hline Design & 7.88 & 530.00 & 5.96 & 11000.00 \\
\hline $\mathbf{1 6 0}$ & 4.93 & 198.30 & 5.30 & 6818.00 \\
\hline $\mathbf{1 7 0}$ & 5.24 & 210.70 & 5.63 & 7356.00 \\
\hline $\mathbf{1 8 0}$ & 5.55 & 223.10 & 5.97 & 7910.00 \\
\hline $\mathbf{1 9 0}$ & 5.86 & 235.50 & 6.30 & 8479.00 \\
\hline $\mathbf{2 0 0}$ & 6.16 & 247.90 & 6.63 & 9062.00 \\
\hline $\mathbf{2 1 0}$ & 6.47 & 260.30 & 6.96 & 9661.00 \\
\hline $\mathbf{2 2 0}$ & 6.78 & 272.70 & 7.29 & 10280.00 \\
\hline
\end{tabular}

Table 6 Additional Cost required to fulfil the gas feed quantity increasing.

\begin{tabular}{|cccccc|}
\hline $\begin{array}{c}\text { Gas } \\
\text { Rate }\end{array}$ & $\begin{array}{c}\text { Glycol re- } \\
\text { boiler }\end{array}$ & $\begin{array}{c}\text { G/G } \\
\text { Exchanger }\end{array}$ & $\begin{array}{c}\text { Chiller of } \\
\text { MIRU-I }\end{array}$ & $\begin{array}{c}\text { Mole } \\
\text { Sieve }\end{array}$ & Cold Box \\
\hline $\mathbf{1 6 0}$ & 0.00 & 0.00 & 0.00 & 0.00 & 0.36 \\
\hline $\mathbf{1 7 0}$ & 0.00 & 0.00 & 0.00 & 0.24 & 0.45 \\
\hline $\mathbf{1 8 0}$ & 0.00 & 0.02 & 0.00 & 0.54 & 0.53 \\
\hline $\mathbf{1 9 0}$ & 0.00 & 0.16 & 0.00 & 0.80 & 0.61 \\
\hline $\mathbf{2 0 0}$ & 0.04 & 0.27 & 0.00 & 1.04 & 0.69 \\
\hline $\mathbf{2 1 0}$ & 0.11 & 0.37 & 0.63 & 1.27 & 0.76 \\
\hline $\mathbf{2 2 0}$ & 0.17 & 0.46 & 1.20 & 1.49 & 0.84 \\
\hline
\end{tabular}

Table 7 Additional cost required related to gas feed quantity increasing.

\begin{tabular}{|c|c|c|c|c|}
\hline \multirow{2}{*}{$\begin{array}{l}\text { Gas } \\
\text { Rate }\end{array}$} & \multirow{2}{*}{$\begin{array}{l}\text { Turbo } \\
\text { Expander }\end{array}$} & \multicolumn{2}{|c|}{ De-ethanizer } & \multirow{2}{*}{$\begin{array}{c}\text { Stabilized } \\
\text { Condensate cooler }\end{array}$} \\
\hline & & Condenser & Re-boiler & \\
\hline 160 & 0.00 & 2.09 & 0.03 & 0.00 \\
\hline 170 & 0.00 & 2.40 & 0.05 & 0.00 \\
\hline 180 & 0.00 & 2.70 & 0.06 & 0.00 \\
\hline 190 & 0.23 & 2.99 & 0.08 & 0.03 \\
\hline 200 & 0.40 & 3.28 & 0.09 & 0.05 \\
\hline 210 & 0.56 & 3.56 & 0.11 & 0.07 \\
\hline 220 & 0.70 & 3.83 & 0.12 & 0.09 \\
\hline
\end{tabular}

Table 8 Additional cost required related to gas feed quantity increasing.

\begin{tabular}{|cccccc|}
\hline $\begin{array}{c}\text { Gas } \\
\text { Rate }\end{array}$ & $\begin{array}{c}\text { Fired } \\
\text { capital } \\
\text { investment }\end{array}$ & $\begin{array}{c}\text { Opera } \\
\text { ting } \\
\text { cost }\end{array}$ & $\begin{array}{c}\text { Total } \\
\text { capital } \\
\text { investment }\end{array}$ & $\begin{array}{c}\text { Revenu } \\
\text { e, MMS }\end{array}$ & $\begin{array}{c}\text { Increme } \\
\text { nt, MMS }\end{array}$ \\
\hline $\mathbf{1 6 0}$ & 12.47 & 2.16 & 12.84 & 355.56 & 7.21 \\
\hline $\mathbf{1 7 0}$ & 15.79 & 2.32 & 16.26 & 368.36 & 20.01 \\
\hline $\mathbf{1 8 0}$ & 19.43 & 2.47 & 20.01 & 381.25 & 32.90 \\
\hline $\mathbf{1 9 0}$ & 24.70 & 2.62 & 25.44 & 394.14 & 45.79 \\
\hline $\mathbf{2 0 0}$ & 29.53 & 2.76 & 30.42 & 406.94 & 58.59 \\
\hline $\mathbf{2 1 0}$ & 37.47 & 2.92 & 38.59 & 419.80 & 71.45 \\
\hline $\mathbf{2 2 0}$ & 44.81 & 3.07 & 46.16 & 432.69 & 84.34 \\
\hline
\end{tabular}


Table 9 Calculated ROlas a function of the gas feed quantity.

\begin{tabular}{|ccc|}
\hline $\begin{array}{c}\text { Gas } \\
\text { Rate }\end{array}$ & ROI, $\%$ & Time, months \\
\hline $\mathbf{1 6 0}$ & 39 & 21.4 \\
\hline $\mathbf{1 7 0}$ & 109 & 9.8 \\
\hline $\mathbf{1 8 0}$ & 152 & 7.3 \\
\hline $\mathbf{1 9 0}$ & 170 & 6.7 \\
\hline $\mathbf{2 0 0}$ & 184 & 6.2 \\
\hline $\mathbf{2 1 0}$ & 178 & 6.5 \\
\hline $\mathbf{2 2 0}$ & 176 & 6.6 \\
\hline
\end{tabular}

\section{References}

[1] Mokhatab, S., Poe, W. A., Speight, J. G., "handbook of natural gas transmission and processing", Elsevier, 2006.

[2] http://www.bentekenergy.com/NGL.aspx

[3] William J. Colt, "Improve Your Project via Effective Scope Definition and Control", Chemical Engineering Progress, March, 1997, page 42.

[4] Kent A. P., Scott E. W., Steven W. C., Thomas R. R., "A Comparative Study of Propane Recovery Processes" River City Engineering, Inc.Lawrence, Kansas, www.rivercityeng.com/pdfzip/C3Recov ery.pdf.

[5] Joe T. L., John D. W., Hank M. H., and Richard N. P., "Process retrofits maximize the value of existing NGL and LPG recovery plants", Ortloff Engineers, Ltd. 2003, Midland, Texas.

[6] El-Wastani petroleum company operation and maintenance commissioning protocol 2006.

[7] Perry R. H.(editor), "Chemical Engineers Handbook". 6th edition McGraw Hill, 1997.

[8] "Advanced Process Modeling Using HYSYS", AspenTech. 2009

[9] Max, S. P., Klaus, D. T., "Plant Design and Economics for Chemical Engineers", Fourth Edition McGrawHill, Inc. 1991

[10] Carl R. B., Editor, "rulesof thumb for chemicalengineers a manual of quick, accurate solutions to everyday process engineering problems", Fourth Edition 2005.

[11] Material department of El-Wastani petroleum company "purchased order of phase-3", Damietta, Egypt 2005

[12] Khabibullin, E., Febrianti, F., Sheng, J., and Bandyopadhyay, S., Et al, "Process Design and Economic Investigation of LPG Production from Natural Gas Liquids (NGL)", NTNU, TKP4170 Process design. Project, 2010

[13] Harron, A. M. A., "Modification of the process of LPG production from natural gas in el-Qar'aa LPG plant", Master thesis, Cairo university, Cairo, 2000.

[14] Campbell J. M, Maddox R. N., Hubbard R. A., Gas conditioning and processing, Vol.3 John Campbell Petroleum series, Norman, Oklahoma, USA (1984)

[15] Solan, E. D., Koh, A. K., "Clathrate hydrate of Natural Gases" 3rd edition, CRC press Taylor and Francis group, USA 2008.

[16] Speight, J., "The chemistry and Technology of Petroleum", 4th edition, Taylor and Francis Group, Boca Raton, USA 2006.
[17] David L. T., James P. K., Kraemer D. L., "Solid hydrocarbon solubility in liquid methane-ethane mixtures along three-phase solid-liquid-vapor loci" J. Chem. Eng. Data, 1979, 24 (4), pp 306- 310 DOI: 10.1021/je60083a013 Publication Date: October 1979

[18] Jou, F.-Y., F. D. Otto, and A. E. Mather, "Solubility of Methane in Glycols at Elevated Pressures," The Canadian Journal of Chemical Engineering, Vol. 72, p. 130-133, February, 1994

[19] Mujtabal.M.,'Batch Distillation Design and Operation', series on chemical engineering, Vol.3, Imperial College Press, London, UK 2004.

[20] Page S. B., William L. L., Joseph P. S., "Design of Distillation Column Control Systems", Instrument Society of America, North Carolina, USA 1985. 